\title{
Involvement of GTA protein NC2 $\beta$ in Neuroblastoma pathogenesis suggests that it physiologically participates in the regulation of cell proliferation
}

Cinzia Di Pietro1, Marco Ragusa1, Davide Barbagallo1ㄴ, Laura R Duro ${ }^{1}$, Maria R Guglielmino ${ }^{1}$, Alessandra Majorana ${ }^{1}$, Veronica Giunta ${ }^{1}$, Antonella Rapisarda ${ }^{1}$, Elisa Tricarichi ${ }^{1}$, Marco Miceli ${ }^{1}$, Rosario Angelica ${ }^{1}$, Agata Grillo $^{2}$, Barbara Banelli ${ }^{3}$, Isabella Defferari ${ }^{4}$, Stefano Forte ${ }^{1}$, Alessandro Laganà ${ }^{1}$, Camillo Bosco ${ }^{1}$, Rosalba Giugno ${ }^{5}$, Alfredo Pulvirenti ${ }^{5}$, Alfredo Ferro ${ }^{1}$, Karl H Grzeschik ${ }^{6}$, Andrea Di Cataldo ${ }^{7}$, Gian P Tonini ${ }^{4}$, Massimo Romani ${ }^{3}$ and Michele Purrello*1

Address: ${ }^{1}$ Dipartimento di Scienze Biomediche, Sezione di Biologia Generale, Biologia Cellulare, Genetica Molecolare G Sichel, Unità di Biologia Genomica e dei Sistemi Complessi, Genetica, Bioinformatica, Università di Catania, 95123 Catania, Italy, ${ }^{2}$ Labogen, 95124 Catania, Italy, ${ }^{3}$ Istituto Nazionale per la Ricerca sul Cancro (IST), Sezione di Genetica dei Tumori, 16132 Genova, Italy, ${ }^{4}$ Istituto Nazionale per la Ricerca sul Cancro (IST), Sezione di Oncologia Traslazionale Pediatrica, 16132 Genova, Italy, ${ }^{5}$ Dipartimento di Matematica ed Informatica, Università di Catania, 95123 Catania, Italy, ${ }^{6}$ Medizinisches Zentrum für Humangenetik, Philipps Universität, 35037 Marburg, Germany and ${ }^{7}$ Dipartimento di Pediatria,

Università di Catania, 95123 Catania, Italy

Email: Cinzia Di Pietro - dipietro@unict.it; Marco Ragusa - mragusa@unict.it; Davide Barbagallo - dbarbaga@unict.it; Laura R Duro - durolaura@unict.it; Maria R Guglielmino - mrguglielmino@gmail.com; Alessandra Majorana - amajorana@dmi.unict.it; Veronica Giunta - ggiunta@unict.it; Antonella Rapisarda - arapisa@unict.it; Elisa Tricarichi - elisa.tricarichi@inwind.it; Marco Miceli - miceli@unict.it; Rosario Angelica - rosarioangelica@studenti.unict.it; Agata Grillo - segreteria@labogen.it; Barbara Banelli - barbara.banelli@istge.it; Isabella Defferari - tonini@cba.unige.it; Stefano Forte - stefano@stefanoforte.it; Alessandro Laganà - lagana@dmi.unict.it; Camillo Bosco - bosco.camillo@tiscali.it; Rosalba Giugno - giugno@dmi.unict.it; Alfredo Pulvirenti - apulvirenti@dmi.unict.it; Alfredo Ferro - ferro@dmi.unict.it; Karl H Grzeschik - grzeschi@staff.uni-marburg.de; Andrea Di Cataldo - adicata@unict.it; Gian P Tonini - tonini@cba.unige.it; Massimo Romani - massimo.romani@istge.it;

Michele Purrello* - purrello@unict.it

* Corresponding author

This article is available from: http://www.molecular-cancer.com/content/7///52

(c) 2008 Di Pietro et al; licensee BioMed Central Ltd.

This is an Open Access article distributed under the terms of the Creative Commons Attribution License (http://creativecommons.org/licenses/by/2.0), which permits unrestricted use, distribution, and reproduction in any medium, provided the original work is properly cited.

\footnotetext{
Abstract

Background: The General Transcription Apparatus (GTA) comprises more than one hundred proteins, including RNA Polymerases, GTFs, TAFs, Mediator, and cofactors such as heterodimeric NC2. This complexity contrasts with the simple mechanical role that these proteins are believed to perform and suggests a still uncharacterized participation to important biological functions, such as the control of cell proliferation.

Results: To verify our hypothesis, we analyzed the involvement in Neuroblastoma (NB) pathogenesis of GTA genes localized at Ip, one of NB critical regions: through RT-PCR of fifty eight NB biopsies, we demonstrated the statistically significant reduction of the mRNA for NC2 $\beta$ (localized at Ip22.I) in 74\% of samples ( $p=0.0039$ ). Transcripts from TAFI3 and TAFI 2 (mapping at IpI3.3 and Ip35.3, respectively) were also reduced, whereas we didn't detect any quantitative
} 
alteration of the mRNAs from GTF2B and NC2 $\alpha$ (localized at Ip22-p2 I and I I q I 3.3, respectively). We confirmed these data by comparing tumour and constitutional DNA: most NB samples with diminished levels of NC2 $\beta$ mRNA had also genomic deletions at the corresponding locus.

Conclusion: Our data show that NC2 $\beta$ is specifically involved in NB pathogenesis and may be considered a new NB biomarker: accordingly, we suggest that NC2 $\beta$, and possibly other GTA members, are physiologically involved in the control of cell proliferation. Finally, our studies unearth complex selective mechanisms within NB cells.

\section{Background}

Transcription initiation, the most important and regulated event along the pathway connecting genotype to phenotype, is governed by the General Transcription Apparatus (GTA): GTA proteins constitute the PreInitiation Complex (PIC) and guide its assembly [1-3]. Class II $\mathrm{PIC}$, larger than $2 \mathrm{MDa}$, comprises more than fifty different polypeptides, including RNA polymerase II, GTFs, Mediator [4-6]. GTF2D consists of the TATA Box - Binding Protein (TBP) and TBP - Associated Factors (TAFs), a group of evolutionarily conserved proteins that participate in determining the state of chromatin, contribute to promoter recognition, serve as coactivators, and posttranslationally modify other GTA proteins to facilitate PIC assembly and transcription initiation $[1,5]$. Its DNA binding activity is regulated by positive and negative cofactors such as heterodimeric NC2 (also named Dr1/Drap 1), comprised of $\alpha$ - and $\beta$-type subunits $[7,8]$. The molecular actions of GTA proteins were clarified through an extensive series of studies $[1-3,6,9]$. On the other hand, only scanty success was obtained in identifying their biological functions as well as in verifying their involvement in genetic pathology, including tumorigenesis [10,11]. We examined the involvement of GTA proteins in the pathogenesis of Neuroblastoma (NB), exploiting our data and those from the literature on the genomics of GTA (see Additional file 1; reviewed in ref. [12]) to perform the positional and functional gene candidate approach. NB is a group of early childhood tumours with a complex molecular pathogenesis $[13,14]$. It is generally believed that the abnormally proliferating cell in all types of NB is the neuroblast, a fleeting stem cell that transiently appears during the early stages of mammalian development [15]. NB clinical phenotype is remarkably heterogeneous, ranging from spontaneous regression to restless progression $[14,16]$. This variability is associated to a high genetic heterogeneity. The most important genomic alterations in $\mathrm{NB}$ are interstitial deletions at 1p, 11q, 17q, and MYCN amplification [14,17]. NB molecular phenotype is characterized by the altered expression of a plethora of genes belonging to different Gene Ontology categories: all of them are potential NB biomarkers $[14,18]$. Our analysis was initially focused on human chromosome 1 short arm, where one or more NB master genes are thought to reside $[17,19]$. In this region, we had previously mapped the genes encoding TAF13, GTF2B, NC2 $\beta$, TAF12 to $1 \mathrm{p} 13.3$, 1p21-p22, 1p22.1, 1p35.3, respectively [20-22].

\section{Methods \\ NB samples}

NB patients were 30 males and 28 females. Tumour primary site was adrenal in 33 patients, abdominal nonadrenal in 18 , thoracic in 5, cervical in 2. Tumours were classified according to the International Neuroblastoma Pathology Classification (INPC) [23]. The final pathologic diagnosis fulfilled the International Criteria for Neuroblastoma Diagnosis [13]. Patients were staged according to the International Neuroblastoma Staging

Table I: Primers and RT-PCR conditions for expression analysis

PCR primers

NC2 $\beta$ fw: 5' CGATGATGATCTCACTATCC 3 NC2 $\beta$ rev: 5' GTTGCTGTCTAGCTTTTGC 3'

NC2 $\alpha$ fw: 5' AGACGGACGAAGAGATTGG 3'

NC2 $\alpha$ rev: 5' CATGTCGGGAACAGATGC 3'

GTF2B fw: 5' AGAAGAGCCTGAAGGGAAGAGC 3'

GTF2B rev: 5' CAGCAACACCAGCAATATCTCC 3'

TAFI 2 fw: 5' GAGCAGTTGGATGAAGATGTGG 3'

TAFI2 rev: 5' TGAGATGGCAGGGAAAAGG 3'

TAFI 3 fw: 5' GCAGATGAGGAAGAAGACC 3'

TAFI 3 rev: 5' TATCTTCAACTTGTACTCGACC 3'

$\beta$ actin fw: $5^{\prime}$ GTGCCCATCTATGAGGGTTACG 3'

$\beta$ actin rev: 5' TGATCCACATCTGCTGGAAGG 3'

\section{RT-PCR conditions}

\author{
$50^{\circ} \mathrm{C} 30 \mathrm{~min} ;\left(94^{\circ} \mathrm{C} 60 \mathrm{sec}, 47^{\circ} \mathrm{C} 90 \mathrm{sec}, 72^{\circ} \mathrm{C} 2 \mathrm{~min}\right) 25 \times ; 72^{\circ} \mathrm{C} 10 \mathrm{~min}$ \\ $50^{\circ} \mathrm{C} 30 \mathrm{~min} ;\left(94^{\circ} \mathrm{C} 60 \mathrm{sec}, 53^{\circ} \mathrm{C} 90 \mathrm{sec}, 72^{\circ} \mathrm{C} 2 \mathrm{~min}\right) 27 \times ; 72^{\circ} \mathrm{C} 10 \mathrm{~min}$ \\ $50^{\circ} \mathrm{C} 30 \mathrm{~min} ;\left(94^{\circ} \mathrm{C} 60 \mathrm{sec}, 50^{\circ} \mathrm{C} 90 \mathrm{sec}, 72^{\circ} \mathrm{C} 2 \mathrm{~min}\right) 27 \times ; 72^{\circ} \mathrm{C} 10 \mathrm{~min}$. \\ $50^{\circ} \mathrm{C} 30 \mathrm{~min} ;\left(94^{\circ} \mathrm{C} 60 \mathrm{sec}, 57^{\circ} \mathrm{C} 90 \mathrm{sec}, 72^{\circ} \mathrm{C} 2 \mathrm{~min}\right) 26 \times ; 72^{\circ} \mathrm{C} 10 \mathrm{~min}$. \\ $50^{\circ} \mathrm{C} 30 \mathrm{~min} ;\left(94^{\circ} \mathrm{C} 60 \mathrm{sec}, 54^{\circ} \mathrm{C} 90 \mathrm{sec}, 72^{\circ} \mathrm{C} 2 \mathrm{~min}\right) 27 \times ; 72^{\circ} \mathrm{C} 10 \mathrm{~min}$. \\ $50^{\circ} \mathrm{C} 30 \mathrm{~min} ;\left(94^{\circ} \mathrm{C} 60 \mathrm{sec}, 46^{\circ} \mathrm{C} 90 \mathrm{sec}, 72^{\circ} \mathrm{C} 2 \mathrm{~min}\right) 25 \times ; 72^{\circ} \mathrm{C} 10 \mathrm{~min}$.
}


System: 12 patients were at stage I, 8 at stage II, 6 at stage III, 23 at stage IV, and 9 at stage IVS. The clinical and molecular characteristics of the patients are reported (see Additional file 2).

\section{Expression of TAFI3, GTF2B, NC2 $\alpha$, TAFI2, NC2 $\beta$}

Total RNA from NB biopsies and from peripheral blood of ten normal controls (BL) was isolated according to our published protocol [12]. Primers were designed with the OMIGA 2.0 software (Oxford Molecular) by using as template the published sequences of Homo sapiens genes: their sequence and corresponding RT-PCR conditions are shown in Table 1 . Transcript reduction was determined by calculating the arithmetic mean of the densitometric values of all samples and using this value as cut-off: only differences that were at least threefold were considered significant to this study.

\section{Genomics of TAFI3, NC2 $\beta$, TAFI 2 in NB samples}

Microsatellite polymorphic markers were selected from the Marshfield map [24] as close as possible to the 5' and 3 ' ends of TAF13, GTF2B, NC2 $\beta$, TAF12 (Table 2, Figure 1). Primers for sequencing were designed with the same software; their sequence was: NC2 $\beta S$ : gtgggtgggggaagg; TAF12S: agggtgtatttatatatagttta; TAF13S: tcccaactaattacactact. PCR was performed according to standard protocols (Invitrogen). Tumour and constitutional (blood) DNA (3 to $5 \mathrm{ng}$ depending on primers efficiency) was amplified with a Master Cycler Gradient (Eppendorf). Forward primers were labeled at their 5' with the fluorochromes Tamra, Joe or 6-Fam (MWG Biotech). Amplified DNA was loaded on ABI PRISM ${ }^{\mathrm{TM}} 310$ Genetic Analyzer (Applied Biosystems): the results were analyzed with ABI PRISM 310 GeneScan 3.1 software. GI was determined by comparing the allelic ratios between constitutional and tumour DNA in heterozygous samples [25]. Theoretically

Table 2: Microsatellite polymorphic markers used for $\mathrm{Gl}$ analysis

\begin{tabular}{|c|c|c|c|c|c|c|}
\hline Locus & Marker & $\begin{array}{c}\text { Chromos } \\
\text { omal } \\
\text { Position }\end{array}$ & Heterozygosity & PCR primers & Size (bp) & PCR conditions \\
\hline NC2 $\beta 5^{\prime}$ & DIS2776 & $\begin{array}{l}92982656 \\
- \\
92982869\end{array}$ & 0.75 & $\begin{array}{l}\text { 5' AATGCCTGTCTTTATCCCTG 3' } \\
\text { 5' AATGTAAGAGAAATGCCCCT 3' }\end{array}$ & $196-212$ & $\begin{array}{c}95^{\circ} \mathrm{C} 10 \mathrm{~min}\left(95^{\circ} \mathrm{C} 30 \mathrm{sec}\right. \\
\left.52^{\circ} \mathrm{C} 75 \mathrm{sec}, 72^{\circ} \mathrm{C} 30 \mathrm{sec}\right) \\
30 \times ; 72^{\circ} \mathrm{C} 10 \mathrm{~min}\end{array}$ \\
\hline NC2 $\beta 33^{\prime}$ & DIS28I3 & $\begin{array}{c}95036107 \\
- \\
95036299\end{array}$ & 0.72 & $\begin{array}{c}\text { 5' CTTTTGACTCACTGGAAGACAT 3' } \\
\text { 5' CCCCACCGTATCTGGTAT 3' }\end{array}$ & $185-205$ & $\begin{array}{c}95^{\circ} \mathrm{C} 10 \mathrm{~min}\left(95^{\circ} \mathrm{C} 30 \mathrm{sec}\right. \\
\left.55^{\circ} \mathrm{C} 75 \mathrm{sec}, 72^{\circ} \mathrm{C} 30 \mathrm{sec}\right) \\
30 \times ; 72^{\circ} \mathrm{C} 10 \mathrm{~min}\end{array}$ \\
\hline$N C 2 \beta 3^{\prime}$ & DIS2664 & $\begin{array}{c}95718483 \\
- \\
95718723\end{array}$ & 0.73 & $\begin{array}{l}\text { 5' CAGCCCACAGAATAACACTG 3' } \\
\text { 5' TTCATGCTATGATTTTCCGC 3' }\end{array}$ & $202-254$ & $\begin{array}{c}95^{\circ} \mathrm{C} 10 \mathrm{~min}\left(95^{\circ} \mathrm{C} 30 \mathrm{sec},\right. \\
\left.54^{\circ} \mathrm{C} 75 \mathrm{sec}, 72^{\circ} \mathrm{C} 30 \mathrm{sec}\right) \\
30 \times ; 72^{\circ} \mathrm{C} 10 \mathrm{~min}\end{array}$ \\
\hline TAFI2 5' & DIS2787 & $\begin{array}{c}27999563 \\
- \\
27999728\end{array}$ & 0.76 & $\begin{array}{c}\text { 5' TTTAACCCTGGAAGGTTGAG 3' } \\
\text { 5' ACAGGACAATGCTGTCAGTATG 3' }\end{array}$ & $137-167$ & $\begin{array}{c}95^{\circ} \mathrm{C} 10 \mathrm{~min}\left(95^{\circ} \mathrm{C} 30 \mathrm{sec}\right. \\
\left.52^{\circ} \mathrm{C} 75 \mathrm{sec}, 72^{\circ} \mathrm{C} 30 \mathrm{sec}\right) \\
30 \times ; 72^{\circ} \mathrm{C} 10 \mathrm{~min}\end{array}$ \\
\hline TAFI2 3' & G603I5 & $\begin{array}{c}30205319 \\
- \\
30205625\end{array}$ & - & $\begin{array}{l}\text { 5' AGCTGAGTCAGGGAAACCCATT 3' } \\
\text { 5' TGTGCTCTTCAATGTGTTAGGGA 3' }\end{array}$ & $307-340$ & $\begin{array}{c}95^{\circ} \mathrm{C} 10 \mathrm{~min}\left(95^{\circ} \mathrm{C} 30 \mathrm{sec}\right. \\
\left.56^{\circ} \mathrm{C} 75 \mathrm{sec}, 72^{\circ} \mathrm{C} 30 \mathrm{sec}\right) \\
30 \times ; 72^{\circ} \mathrm{C} 10 \mathrm{~min}\end{array}$ \\
\hline TAFI3 5' & DIS2778 & $\begin{array}{c}108849441 \\
- \\
108849609\end{array}$ & 0.66 & $\begin{array}{l}\text { 5' CACAGTTAAATTGCATTTCC 3' } \\
\text { 5' GCTCACCATAAACAAGAGG 3' }\end{array}$ & $161-173$ & $\begin{array}{c}95^{\circ} \mathrm{C} 10 \mathrm{~min}\left(95^{\circ} \mathrm{C} 30 \mathrm{sec},\right. \\
\left.50^{\circ} \mathrm{C} 75 \mathrm{sec}, 72^{\circ} \mathrm{C} 30 \mathrm{sec}\right) \\
30 \times ; 72^{\circ} \mathrm{C} 10 \mathrm{~min}\end{array}$ \\
\hline TAFI3 3' & DIS22I & $\begin{array}{c}110103235 \\
- \\
110103467\end{array}$ & 0.75 & $\begin{array}{l}\text { 5' CCTACAACTCCATCCTGTCC 3' } \\
\text { 5' GTCTTAAGTCGCTCTGCCTG 3' }\end{array}$ & $215-225$ & $\begin{array}{c}95^{\circ} \mathrm{C} 10 \mathrm{~min}\left(95^{\circ} \mathrm{C} 30 \mathrm{sec}\right. \\
\left.56^{\circ} \mathrm{C} 75 \mathrm{sec}, 72^{\circ} \mathrm{C} 30 \mathrm{sec}\right) \\
30 \times ; 72^{\circ} \mathrm{C} 10 \mathrm{~min}\end{array}$ \\
\hline NC2 $\alpha 3^{\prime}$ & DIISI889 & $\begin{array}{c}67069719 \\
- \\
67069901\end{array}$ & 0.67 & $\begin{array}{l}\text { 5' AGCTGGACTCTCACAGAATG 3' } \\
\text { 5'CAAGAGGCTGGTAGAAGGTG3' }\end{array}$ & $183-207$ & $\begin{array}{c}95^{\circ} \mathrm{C} 10 \mathrm{~min}\left(95^{\circ} \mathrm{C} 30 \mathrm{sec},\right. \\
\left.60^{\circ} \mathrm{C} 30 \mathrm{sec}, 72^{\circ} \mathrm{C} 30 \mathrm{sec}\right) \\
30 \times ; 72^{\circ} \mathrm{C} 10 \mathrm{~min}\end{array}$ \\
\hline NC2 $\alpha 3^{\prime}$ & DIIS4I78 & $\begin{array}{c}67945684 \\
- \\
67945935\end{array}$ & 0.69 & $\begin{array}{l}\text { 5' CAGGCCCAGTCTCTTG 3' } \\
\text { 5' CGTGTCCAGATGAAAGTG 3' }\end{array}$ & $237-260$ & $\begin{array}{c}95^{\circ} \mathrm{C} 10 \mathrm{~min}\left(95^{\circ} \mathrm{C} 30 \mathrm{sec}\right. \\
\left.52^{\circ} \mathrm{C} 75 \mathrm{sec}, 72^{\circ} \mathrm{C} 30 \mathrm{sec}\right) \\
30 \times ; 72^{\circ} \mathrm{C} 10 \mathrm{~min} .\end{array}$ \\
\hline GTF2B 5' & DIS2856 & $\begin{array}{c}82130207 \\
- \\
82130465\end{array}$ & 0.5 & $\begin{array}{c}\text { 5' AGCTCTGTGACATTGGATAA 3' } \\
\text { 5' CAGAACATAATAAGTGTGGCTA 3' }\end{array}$ & $257-263$ & $\begin{array}{c}95^{\circ} \mathrm{C} 10 \mathrm{~min}\left(95^{\circ} \mathrm{C} 30 \mathrm{sec}\right. \\
\left.53^{\circ} \mathrm{C} 75 \mathrm{sec}, 72^{\circ} \mathrm{C} 30 \mathrm{sec}\right) \\
30 \times ; 72^{\circ} \mathrm{C} 10 \mathrm{~min} .\end{array}$ \\
\hline GTF2B 5' & DIS454 & $\begin{array}{c}82540746 \\
- \\
82540872\end{array}$ & 0.56 & $\begin{array}{c}\text { 5' TGTTAGTTCCTGTTCTTGGTGA 3' } \\
\text { 5' TTCCCTGGAAACAACCATAA 3' }\end{array}$ & $155-163$ & $\begin{array}{c}95^{\circ} \mathrm{C} 10 \mathrm{~min}\left(95^{\circ} \mathrm{C} 30 \mathrm{sec}\right. \\
\left.58^{\circ} \mathrm{C} 75 \mathrm{sec}, 72^{\circ} \mathrm{C} 30 \mathrm{sec}\right) \\
30 \times ; 72^{\circ} \mathrm{C} 10 \mathrm{~min}\end{array}$ \\
\hline GTF2B 3' & DIS435 & $\begin{array}{c}91331437 \\
- \\
91331556\end{array}$ & 0.73 & $\begin{array}{l}\text { 5' GGCCACATGGGAATTTTCT 3' } \\
\text { 5' AGCAGTTCAAGGCCACAGT 3' }\end{array}$ & $157-177$ & $\begin{array}{c}95^{\circ} \mathrm{C} 10 \mathrm{~min}\left(95^{\circ} \mathrm{C} 30 \mathrm{sec},\right. \\
\left.55^{\circ} \mathrm{C} 75 \mathrm{sec}, 72^{\circ} \mathrm{C} 30 \mathrm{sec}\right) \\
30 \times ; 72^{\circ} \mathrm{C} 10 \mathrm{~min}\end{array}$ \\
\hline
\end{tabular}




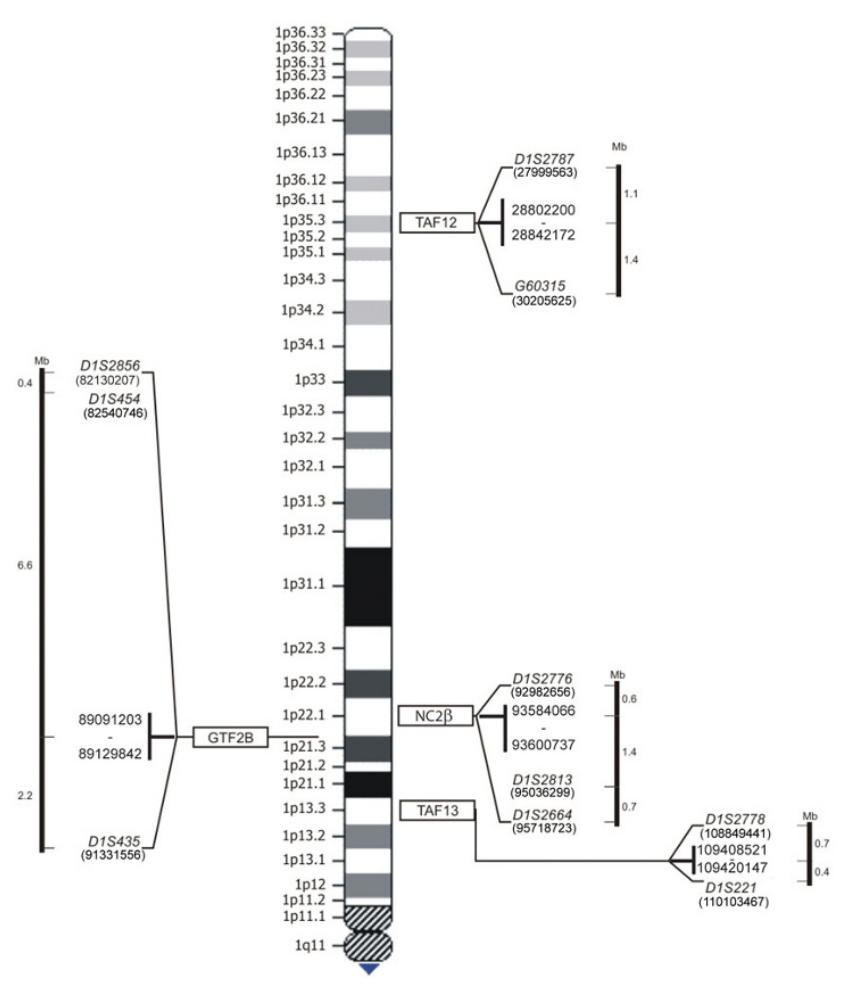

Figure I

Genomics of TAF I3, GTF2B, NC2 $\beta$, TAF I 2. Genomic position of TAFI3, GTF2B, NC2 $\beta$, TAFI 2 and corresponding microsatellite polymorphic markers.

QGI = 0 expresses the total loss of one allele and QGI = 1 indicates the normal allele ratio. We refer to Genomic Imbalance when QGI $\leq 0.5$.

\section{Methylation analysis}

The location of $\mathrm{CpG}$ islands in the bone fide promoter regions of NC2 $\beta$, TAF12 and TAF13 was determined with the CpGPLOT software [26], after masking the repeated sequences with Repeat Masker [27]. The NB samples and cell lines analyzed are listed in Additional file 3. Quantitative methylation analysis was performed by pyrosequencing with a SPQ 96MA instrument (Biotage, Uppsala, Sweden) [28]. Pyrosequencing is a sequencing by synthesis-analysis of short genomic sequences that is ideally suited for SNP analysis. In this respect, DNA methylation can be considered a special case of polymorphism revealed by the bisulfite chemical reaction that converts only the unmethylated Cs into Ts [29]. $2 \mu \mathrm{l}$ of bisulfite modified DNA were amplified with primers designed with the Assay Design Software for Pyrosequencing (Biotage, Uppsala, Sweden) to amplify target sequences independently of their methylation status. The amplified targets were then subjected to pyrosequencing analysis.
Primers sequences were: NC2 $\beta F$ : gttttgtgaaggaatggga; NC2 $\beta R$ : tcaaatttcccctccct (amplicon size: 153 bp, Ta $\left.58^{\circ} \mathrm{C}\right)$; TAF12F: aagagtaagttgtagggtgtattt; TAF12R: acaaaaactaccccaataaaa (amplicon size: $214 \mathrm{bp}$, Ta $58^{\circ} \mathrm{C}$ ); TAF13F: ggttttttttttagagattgt; TAF13R: aaaatcttcttcctcatctactacca (amplicon size: 208 bp, Ta $58.5^{\circ} \mathrm{C}$ ). Sequencing reactions were performed with the Pyro Gold reagent kit SPQ 96MA according to the manufacturer instructions (Biotage, Uppsala, Sweden).

\section{Statistical analysis}

We correlated our data by using an A-Priori data mining algorithm for tables with Unknown Values corresponding to missing data [30]. Let $\mathrm{T}(\mathrm{A} 1, \mathrm{~A} 2, \ldots, \mathrm{Ak})$ be a table with attributes (columns) A1, A2, ..., Ak. Each column Ai is a predicate (truth-value function) that assigns to every row $r$ (experiment) one of the three values: True, False, Unknown. This means that $\mathrm{Ai}(\mathrm{r})=$ True/False/Unknown indicates that $\mathrm{Ai}$ holds/does not hold/is unknown in the experiment r. For example, rows may be NB samples and columns may be RT-PCR or GI data. In this case, $\mathrm{Ai}(\mathrm{r})=$ True (resp. False, resp. Unknown) may indicate that gene $\mathrm{Ai}$ is overexpressed (resp. is not overexpressed, resp. could not be unambiguously assigned a value) in sample $\mathrm{r}$. Datamining searches for highly related facts that constitute a frequent itemset. Any datamining algorithm tries to construct the collection $\mathrm{Lj}$ of all frequent itemsets $\mathrm{S}$ of size j.

\section{Definition I}

(frequent itemset). Given a positive threshold t, a frequent itemset $\mathrm{S}$ of size j includes j columns Ai1, Ai2, ..., Aij such that the ratio [Number of rows $r$ in which (Ai1(r) AND*Ai2(r) AND* ... AND* Aij(r)) = True]/[Number of rows $r$ in which $\left(\mathrm{Ai} 1(\mathrm{r}) \mathrm{AND}^{*} \mathrm{Ai} 2(\mathrm{r}) \mathrm{AND}^{*} \ldots \mathrm{AND}^{*}\right.$ $\operatorname{Aij}(\mathrm{r})) \neq \mathrm{UNKNOWN]}>\mathrm{t}$.

The commutative three-valued logical conjunction AND* is an extension of the classical logical conjunction by the following table rows:

\section{A B A AND* B}

\section{True Unknown Unknown}

False Unknown False

\section{Unknown Unknown Unknown}

The A-priori datamining algorithm exploits the monotonicity property: this in the classic two-valued logic (true/ false) implies that subsets of frequent sets are themselves frequent. However, in the presence of Unknown Values this notion must be slightly modified in the following way. 

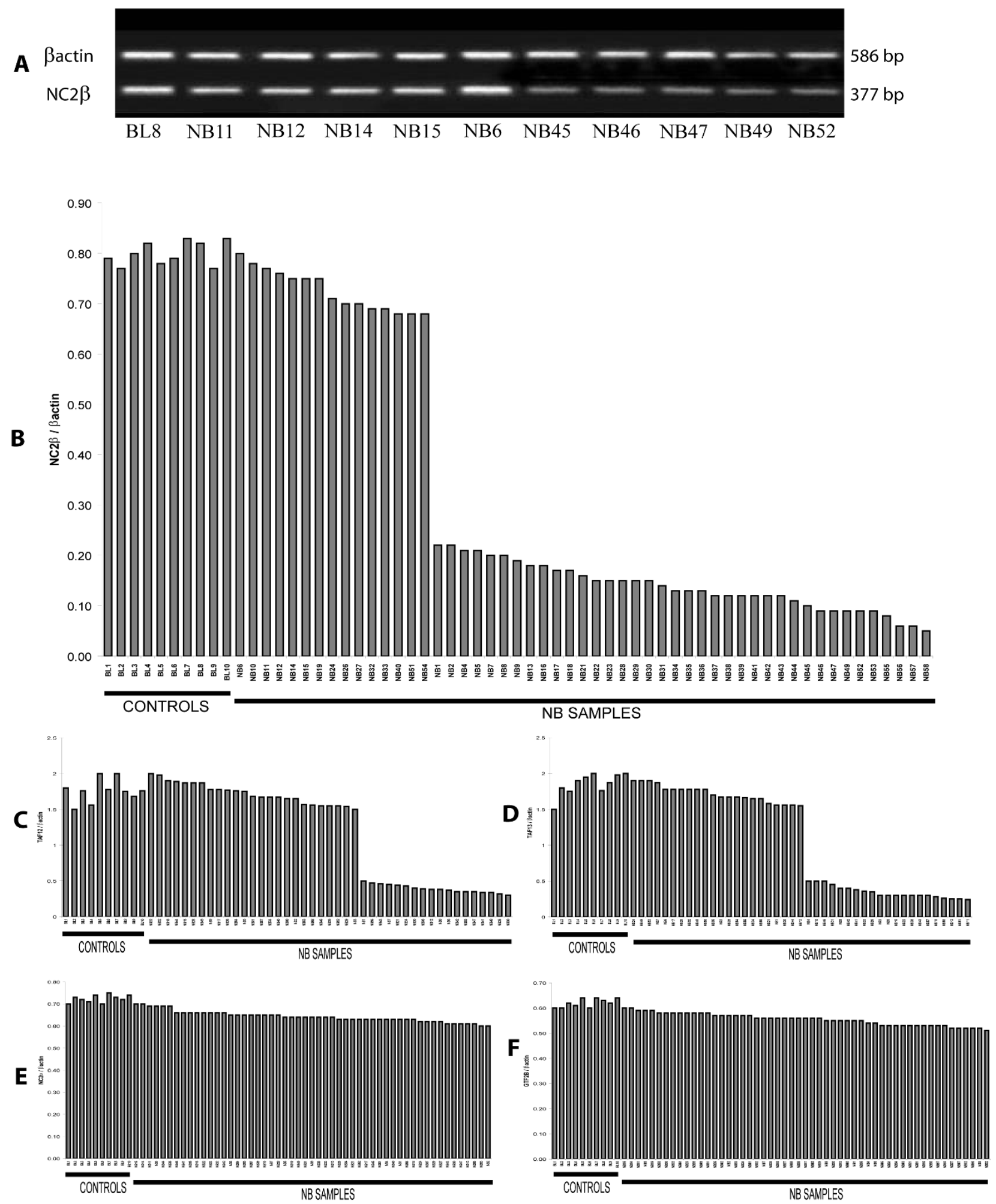

Figure 2

TAF 13, GTF2B, NC2 $\alpha$, TAF I 2, NC2 $\beta$ expression in NB samples. A: RT-PCR analysis of NC2 $\beta$ expression in a control (BL8) and in NB samples. B, C, D: Diminished expression of NC2 $\beta$, TAFI2, TAFI3 in NB samples with respect to human adult peripheral blood (BL). E, F: Similar expression of GTF2B and NC2 $\alpha$ in control and NB samples. 

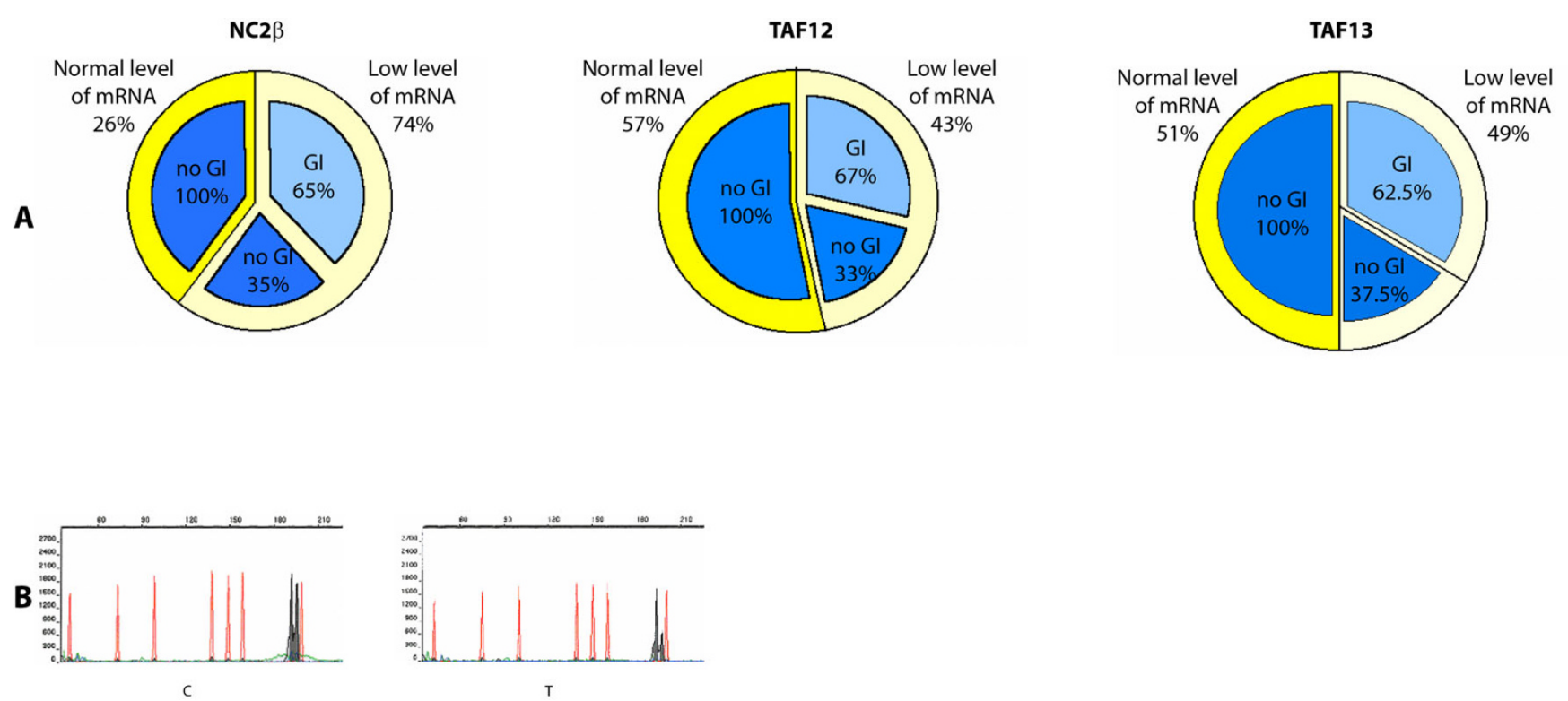

Figure 3

Genotype/phenotype correlation in neuroblastoma. A: Normal levels of the mRNAs encoding NC2 $\beta$, TAFI 2, TAFI 3 always correspond to Gl absence. Low levels of these mRNA species are frequently associated with GI. B: Densitometric pattern of microsatellites showing GI at the locus NC2 $\beta$ in a NB sample (T) and its absence in the blood (C) from the same individual.

Table 3: Correlation between decrease of GTA genes mRNA and NB phenotype

\begin{tabular}{cccc}
\hline & NC2 $\beta$ & TAFI3 & TAFI2 \\
\hline NB patients with mRNA decrease & $73.6 \%(39 / 53)$ & $48.8 \%(21 / 43)$ & $43.2 \%(19 / 44)$ \\
NB patients with normal mRNA levels & $26.4 \%(14 / 53)$ & $51.2 \%(22 / 43)$ & $56.8 \%(25 / 44)$ \\
p-value & $\mathbf{0 . 0 0 3 9}$ & 0.543 & 0.527 \\
\hline
\end{tabular}

\section{Definition 2}

(candidate set). A set $\mathrm{S}$ of $\mathrm{j}$ columns Ai1, Ai2, ..., Aij is candidate if

[Number of rows $\mathrm{r}$ in which (Ai1(r) AND* Ai2(r) AND* ... AND $*$ Aij(r)) $=$ True]/[Number of rows $r$ in which there are NOT UNKNOWN values] $>$ t.

Here is the pseudo-code for the A-priori data mining with unknown values

Inizialization step:

Let $\mathrm{C} 1$ be the set of candidate single columns.

Let $\mathrm{L} 1$ be the set of columns Ai in $\mathrm{C} 1$ which are also frequent.

Recursive step:
For each $\mathrm{j}>1$

Let $\mathrm{C} j$ be the set of $\mathrm{j}$ columns Ai1, Ai2, ..., Aij, such that each subset of $\mathrm{j}-1$ columns is in $\mathrm{Cj}-1$.

Let $\mathrm{Lj}$ be the collection of sets in $\mathrm{Cj}$ that are frequent.

Since in practice very few rows have Unknown Values, the speed-up given by the above A-priori strategy is similar to that given by the classical two-valued logic A-priori datamining. To establish the statistical significance of our results, p-values were computed by using Efron multiple hypotheses testing [31].

\section{Results and Discussion}

Based on TAF13, GTF2B, NC2 $\beta$, TAF12 genomic location and molecular functions, we considered these four GTA genes as positional and functional candidates for involvement in NB pathogenesis (see Additional file 1, Table 1 and Figure 1). As reference marker, we used the GTA pro- 


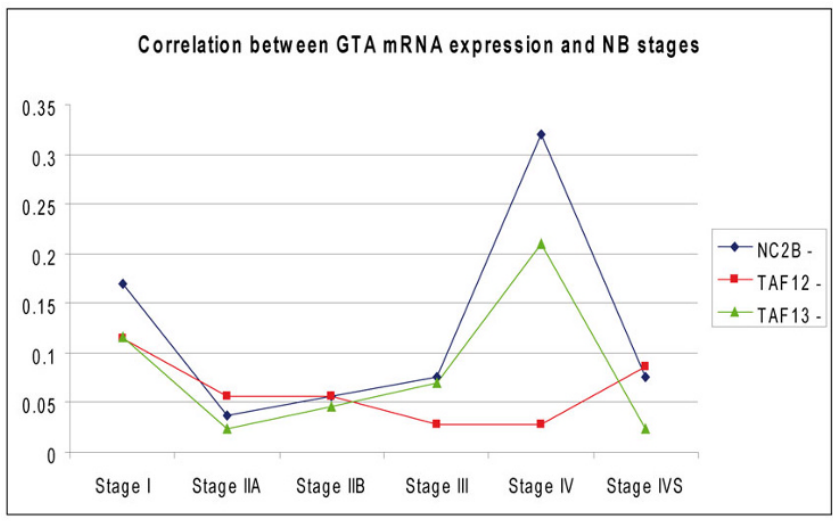

\section{Figure 4}

Correlation between GTA mRNA expression and

NB stages. A statistically significant association exists between NC2 $\beta$ mRNA decrease and NB stages III and IV (4/ 39 and $17 / 39$, respectively) ( $p=0.003937)$. Interestingly, it was also found with stage I $(p=0.003922)$ : this could suggest a stage-specific selection of the NC2 $\beta$ (-) mRNA phenotype.

tein $\mathrm{NC} 2 \alpha$ (the molecular partner of $\mathrm{NC} 2 \beta$ ), that is encoded by a gene located at 11q13.3 (see Additional file 1, Table 1) [32]. Expression of these genes was analyzed through RT - PCR in fifty eight NB biopsies (see Additional file 2, Table 1 and Figure 2). As a preliminary step, we characterized their mRNA phenotype in ten peripheral blood samples from normal individuals and we did not observe significant variations of their transcription level (Table 1, Figure 2). On the other hand, in NB we found a clear-cut decrease (from 3 to 8 times) of the mRNAs encoding TAF13, NC2 $\beta$, TAF12 with respect to peripheral blood from the same individuals in $49 \%(21 / 43), 74 \%$ (39/53), 43\% (19/44) samples, respectively (Figures 2 and 3). Statistical analysis demonstrated a significant positive correlation between NC2 $\beta$ transcripts reduction and NB ( $p=0.0039)$, whereas this was not obtained for TAF13 and TAF12 (Table 3). NC2 $\beta$ mRNA levels are significantly decreased in both NB advanced stages III and IV ( $\mathrm{p}=$ $0.0039)$; their reduction also in stage I $(p=0.0039)$ could suggest a peculiar natural history of NB (Figure 4). In the same set of samples, we did not detect any change of the levels of the mRNAs encoding GTF2B and NC2 $\alpha$ (Figure 2 ). By using at least two closely flanking microsatellite markers for each gene, we then analyzed the genome of the same NB samples for deletions at the loci TAF13, GTF2B, NC2 $\beta$, TAF12, NC2 $\alpha$ (Table 2, Figures 1 and 3): these were found in more than $60 \%$ of samples with diminished levels of the mRNAs encoding either TAF13 $(62.5 \%), \mathrm{NC} 2 \beta(65 \%)$, or TAF12 (67\%), but were never detected in NB samples with normal levels of mRNA for these three genes (Figures 3A, B, 5A). Similarly, we never found deletions at the GTF2B and NC2 $\alpha$ loci both in NB
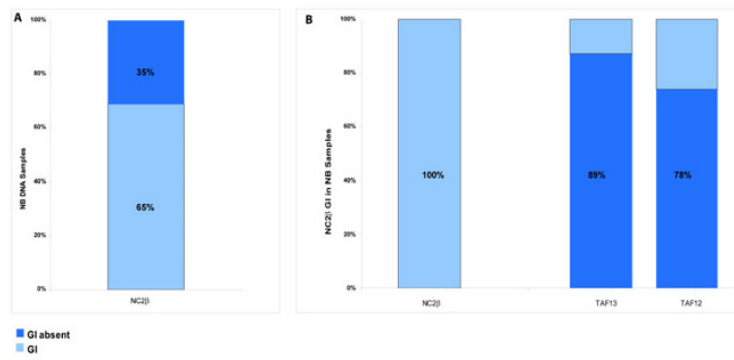

Figure 5

GI frequency at the loci TAF I3, NC2 $\beta$, TAFI2. In NB samples with Genomic Imbalance (Gl) for NC2 $\beta$, we never detect it for TAFI 2 or TAFI3: the anticorrelation between NC2 $\beta$ and TAFI 3 reached statistical significance $(p=0.043)$. TAF 12 and TAF 13 seemed to show a reciprocal positive correlation since in $80 \%$ of samples $\mathrm{Gl}$ was absent in both.

biopsies as well as in controls (not shown). Due to aneuploidy, we suggest that for NB as for other tumours GI (Genomic Imbalance) may be more appropriate than LOH (Loss of Heterozygosity). In NB samples with GI for NC2 $\beta$, we never detect it for TAF12 or TAF13 (Figure 5B): the anticorrelation between $N C 2 \beta$ and TAF13 reached statistical significance $(\mathrm{p}=0.043)$. TAF 12 and TAF 13 seemed to show a reciprocal positive correlation since in $80 \%$ of samples GI was absent in both. Besides genomic deletions, the reduced levels of the mRNAs encoding NC2 $\beta$, TAF12, TAF13 in NB samples could be due to: (i) epigenetic modifications of promoter DNA, such as methylation [33]; (ii) mutations in the promoter or other regulatory regions [34]; (iii) increased mRNA turnover [35]; (iv) negative regulation by miRNAs $[36,37]$. To test the first of these possibilities, we analyzed a panel of NB biopsies and NB cell lines with low levels of mRNAs for these three genes and checked the methylation status of the 4 to 7 CpG doublets found in their bona fide promoter (see Additional file 3, Figure 6). In general, very low or no methylation was observed both in the tumor samples as in the cell lines (see Additional file 3, Figure 6). We did observe higher levels of DNA methylation in the $\mathrm{NC} 2 \beta$ gene, that was however not correlated to its expression with the exception of sample NB41 (Figures 2 and 6): this indicates that other mechanisms, such as negative regulation by microRNAs, should be considered to account for the low levels of expression of these genes in NB [36,37]. Our data allow us to speculate on the biological role of GTA proteins NC2, TAF12, TAF13, GTF2B. NC2 is an evolutionarily conserved transcriptional regulator for which an intriguing general role was proposed: it could repress basal transcription in the absence of activators or alternatively stimulate it in their presence [9]. Analogously to p53 role as Guardian of the Genome, NC2 could represent the Guardian of the Transcription Machinery and control its 


\section{exon 1}

A

\section{$\mathrm{NC2} \beta$}

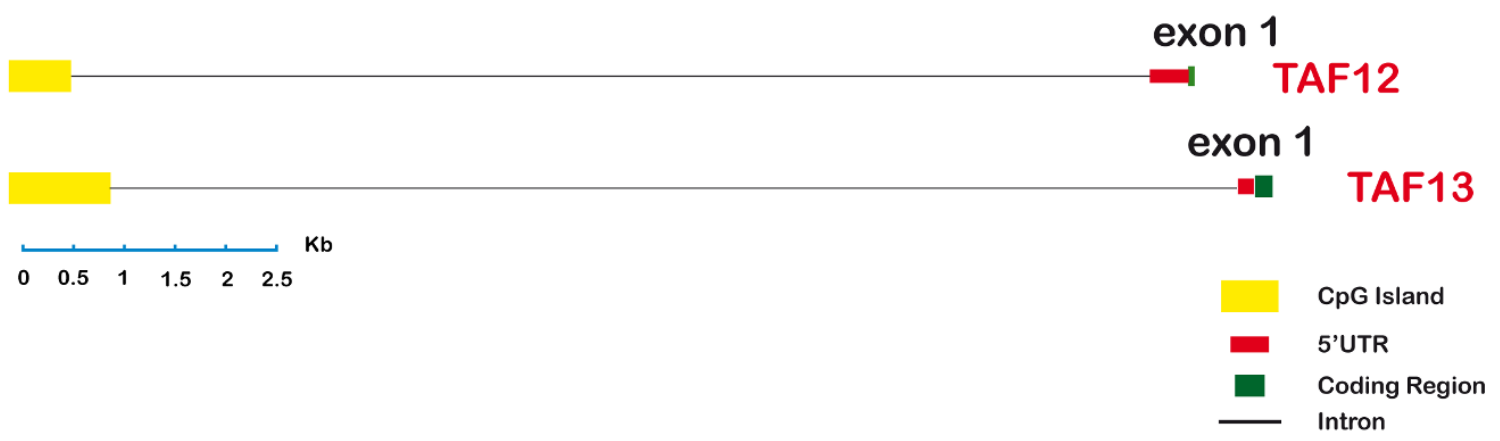

B

\begin{tabular}{|c|c|c|c|c|c|}
\cline { 2 - 6 } \multicolumn{1}{c|}{} & \multicolumn{5}{c|}{ NC 23 } \\
\cline { 2 - 6 } \multicolumn{1}{c|}{} & CG site & C G site & CG site & C G site & C G site \\
\hline CTRL & 0 & 4 & 2.9 & 0 & 5.6 \\
\hline NB1 & 1.9 & 3.3 & 1.9 & 4 & 5.4 \\
\hline NB5 & 3.3 & 4.6 & 2.9 & 6.8 & 6.3 \\
\hline NB7 & 0 & 2.7 & 1.9 & 2.5 & 4.7 \\
\hline NB8 & 2.8 & 3.8 & 0 & 5.2 & 6.3 \\
\hline NB13 & 1.3 & 2.6 & 1.7 & 2.3 & 5.6 \\
\hline NB41 & 15 & 22.3 & 7.2 & 40.6 & 26.8 \\
\hline NB56 & 1.7 & 2.6 & 0 & 3 & 4.5 \\
\hline
\end{tabular}

\begin{tabular}{|l|c|c|c|c|}
\cline { 2 - 5 } \multicolumn{1}{c|}{} & \multicolumn{5}{c|}{ NC23 } \\
\cline { 2 - 5 } \multicolumn{1}{c|}{} & CG site & CG site & CG site & CG site \\
\hline CTRL & 1 & 2 & 3 & 4 \\
\hline ACN & 0 & 0 & 0 & 0 \\
\hline GICAN & 0 & 0 & 8.42 & 0 \\
\hline GIMEN & 0 & 0 & 0 & 0 \\
\hline IMR32 & 5.51 & 0.31 & 11.12 & 0 \\
\hline LAN1 & 0 & 0 & 11.17 & 7.67 \\
\hline LAN5 & 0 & 0 & 19.57 & 0 \\
\hline SHSY5Y & 0 & 0 & 0 & 0 \\
\hline SKNBE & 0 & 0 & 0 & 0 \\
\hline SKNSH & 0 & 0 & 0 & 24.4 \\
\hline
\end{tabular}

\section{Figure 6}

Methylation of NC2 $\beta$ promoter. A: CPG islands upstream and downstream of NC2 $\beta$, TAFI2, TAFI3 transcription start site. B: Methylation percentage of CPG sites within NC2 $\beta$ island. Samples with methylation levels below $10 \%$ are considered unmethylated: accordingly, we suggest that promoter methylation may explain the low NC2 $\beta$ mRNA expression only in sample NB4I (Figure 2). For methylation analysis of TAFI2 and TAFI3 promoter, (see Additional file 3).

balanced functioning, performing a role as tumor suppressor possibly not restricted to NB: reduced levels of the protein could be responsible for the inappropriate activation of genes promoting cellular proliferation, thus con- tributing to cell transformation. Its two subunits NC2 $\alpha$ and NC2 $\beta$ could perform distinct roles in the regulation of gene expression and determination of cell phenotype: binding of holoNC2 marks repressed promoters, while 
occupancy by NC2 $\alpha$ correlates with active promoters [38]. TAF12 and TAF13 encode two small subunits of GTF2D. TAF12 interacts directly with TBP [39]. Similar to TAF4b, TAF6 and TAF9, it contains a histone fold domain (HFD): the polypeptide is part of a histone-like TAF complex that was shown to be critically important for GTF2D architecture [40]. TAF13, that interacts with TBP, TAF10 and TAF11, is associated with only a subset of GTF2D complexes [39]. Reduced levels of TAF12 and TAF13 could alter GTF2D structure and function and deregulate the expression of different genes, such as those involved in cell cycle control: different mutations of yTAF25 (the yeast ortholog of TAF12) are known to induce distinct phenotypes and affect the regulation of different subsets of genes [41]. GTF2B is a highly conserved member of GTA [42]: it forms a complex with GTF2D and GTF2A (the DAB complex), bridging RNA polymerase II and the promoter [43]. The protein is also a target of Mediator and gene - specific transcriptional activators [44]. Its critical molecular and biological role could explain our failure to detect GTF2B deletions in NB, since they would expose the cells to a strong negative selection. A similar argument could be put forward to explain the absence of NC2 $\alpha$ deletions in our dataset. Cell proliferation and specularly tumorigenesis are very complex phenomena. Aneuploidy and GI are common features of neoplastic genomes $[45,46]$. The ensuing haploinsufficiency may cause loss of the cell ability to autonomously control its proliferation and to coordinate it with that of other cells of the same organism. Unexpected odd partners seem to be involved in the process. Our approach has allowed us to demonstrate that reduced expression and GI at the GTA locus NC2 $\beta$ is frequently and specifically present in the genome of $\mathrm{NB}$ tumour cells, possibly as a result of mutations of caretaker genes involved in DNA repair or chromosomal segregation and of complex selective mechanisms [14, 46, this paper]. The possible anticorrelation between NC2 $\beta$ on the one side and TAF 12 and TAF 13 on the other may suggest that these proteins could perform analogous biological roles and as such they may reciprocally complement each other as negative regulators of proliferation.

\section{Conclusion}

The data presented in this paper experimentally confirm our hypothesis that at least some GTA proteins may also be physiologically involved in the control of cell proliferation, at the same time underscoring the importance of natural selection within complex biopathological processes $[22,47]$. They also suggest possible ways to exploit molecular omic profiling to determine biological functions and design rational anticancer therapies.

\section{Competing interests}

The authors declare that they have no competing interests.

\section{Authors' contributions}

MP conceived and directed the project. CdP, MR (Ge), $\mathrm{GPT}, \mathrm{AdC}, \mathrm{KHG}, \mathrm{AF}, \mathrm{AG}$ designed some of the experiments. MR (CT), DB, LRD, MRG, AM, VG, AR, ET, MM, $\mathrm{BB}$, ID, SF, AL, CB, RG, AP carried out experiments. MP and $M R(G e)$ wrote the paper.

\section{Additional material}

\author{
Additional file 1 \\ Genomics and Transcriptomics of Human GTA. \\ Click here for file \\ [http://www.biomedcentral.com/content/supplementary/1476- \\ 4598-7-52-S1.xls]

\section{Additional file 2} \\ NB Patients: Clinical, Pathological, Biomolecular Data. \\ Click here for file \\ [http://www.biomedcentral.com/content/supplementary/1476- \\ 4598-7-52-S2.xls]

\section{Additional file 3} \\ Methylation of TAF12 and TAF13 in NB biopsies and NB cell lines. \\ Click here for file \\ [http://www.biomedcentral.com/content/supplementary/1476- \\ 4598-7-52-S3.doc]
}

\section{Acknowledgements}

We thank Dr R Roeder (The Rockefeller University, New York, USA) for his interest in our studies along the years and the Reviewers for their careful analysis and suggestions. We also thank Drs A Battaglia, F Covato, M Santonocito, L Tomasello for collaborating to the experimental work, Mrs M Cocimano, Mr S Galatà, Mr L Messina, Mr F Mondio, Mr A Vasta for technical collaboration. This project was funded by Ministero dell'Università e della Ricerca Scientifica e Tecnologica (MUR) (MP), by Associazione Italiana per la Ricerca sul Cancro (AIRC) (MP and MR), and by Ministero della Salute (MR). Drs D Barbagallo, C Bosco, L Duro, MR Guglielmino, S Forte, A Laganà, A Majorana are PhD Students (Dottorato di Ricerca in Biologia, Genetica Umana, Biolnformatica: Basi Molecolari e Cellulari del Fenotipo - Director: Prof M Purrello). Dr B Banelli is a fellow of the Fondazione Italiana per la Lotta al Neuroblastoma. We regret that due to space limitations we were unable to cite many papers, related to the subject of this work.

\section{References}

I. Roeder RG: The role of general initiation factors in transcription by RNA polymerase II. Trends Biochem Sci 1996, 21:327-35.

2. Geiduschek EP, Kassavetis GA: The RNA polymerase III transcription apparatus. J Mol Biol 200 I, 3 I 0: I-26.

3. Grummt I: Life on a planet of its own: regulation of RNA polymerase I transcription in the nucleolus. Genes Dev 2003. 17:1691-702.

4. Koleske AJ, Young RA: The RNA polymerase II holoenzyme and its implications for gene regulation. Trends Biochem $\mathrm{Sci}$ 1995, 20: I 13-6.

5. Lemon B, Tjian R: Orchestrated response: a symphony of transcription factors for gene control. Genes Dev 2000, I 4:255 I-69.

6. Roeder RG: The eukaryotic transcriptional machinery: complexities and mechanisms unforeseen. Nat Med 2003, 9:1239-44.

7. Kaiser K, Meisterernst M: The human general co-factors. Trends Biochem Sci 1996, 21 :342-5. 
8. Kim S, Na JG, Hampsey M, Reinberg D: The DrI/DRAPI heterodimer is a global repressor of transcription in vivo. Proc Natl Acad Sci USA 1997, 94:820-5.

9. Thomas $M C$, Chiang $C M$ : The general transcription machinery and general cofactors. Crit Rev Biochem Mol Biol 2006, 4I:I05-78.

10. Winter AG, Sourvinos G, Allison SJ, Tosh K, Scott PH, Spandidos DA, White RJ: RNA polymerase III transcription factor TFIIIC2 is overexpressed in ovarian tumors. Proc Natl Acad Sci USA 2000, 97:12619-24.

II. Zurita M, Merino C: The transcriptional complexity of the TFIIH complex. Trends Genet 2003, 19:578-84.

12. Di Pietro $C$, Ragusa M, Duro LR, Guglielmino MR, Barbagallo $D$, Carnemolla A, Laganà A, Buffa $P$, Angelica R, Rinaldi A, Calafato MS, Milicia I, Caserta C, Giugno R, Pulvirenti A, Giunta V, Rapisarda A, Di Pietro V, Grillo A, Messina A, Ferro A, Grzeschik KH, Purrello M: Genomics, Evolution, and Expression of TBPL2, a Member of the TBP Family. DNA Cell Biol 2007, 26(6):369-385.

13. Brodeur GM, Pritchard J, Berthold F, Carlsen NL, Castel V, Castelberry RP, De Bernardi B, Evans AE, Favrot M, Hedborg F: Revisions of the international criteria to neuroblastoma diagnosis, staging and response to treatment. J Clin Oncol 1993, II:1466-77.

14. Brodeur GM: Neuroblastoma: biological insights into a clinical enigma. Nat Rev Cancer 2003, 3:203-16.

15. De Preter K, Vandesompele J, Heimann P, Yigit N, Beckman S, Schramm A, Eggert A, Stallings RL, Benoit Y, Renard M, De Paepe A, Laureys G, Påhlman S, Speleman F: Human fetal neuroblast and neuroblastoma transcriptome analysis confirms neuroblast origin and highlights neuroblastoma candidate genes. Genome Biol 2006, 7:R84.

16. Vandesompele J, Baudis M, De Preter K, Van Roy N, Ambros P, Bown $\mathrm{N}$, Brinkschmidt $\mathrm{C}$, Christiansen $\mathrm{H}$, Combaret $\mathrm{V}$, Lastowska $M$ Nicholson J, O'Meara A, Plantaz D, Stallings R, Brichard B, Broecke C Van den, De Bie S, De Paepe A, Laureys G, Speleman F: Unequivocal delineation of clinicogenetic subgroups and development of a new model for improved outcome prediction in neuroblastoma. J Clin Oncol 2005, 23:2280-99.

17. Wang Q, Diskin S, Rappaport E, Attiyeh E, Mosse Y, Shue D, Seiser E, Jagannathan J, Shusterman S, Bansal M, Khazi D, Winter C, Okawa E, Grant G, Cnaan A, Zhao H, Cheung NK, Gerald W, London W, Matthay KK, Brodeur GM, Maris JM: Integrative genomics identifies distinct molecular classes of neuroblastoma and shows that multiple genes are targeted by regional alterations in DNA copy number. Cancer Res 2006, 66:6050-62.

18. Riley RD, Heney D, Jones DR, Sutton AJ, Lambert PC, Abrams KR, Young B, Wailoo AJ, Burchill SA: A systematic review of molecular and biological tumor markers in neuroblastoma. Clin Cancer Res 2004, 10:4-12.

19. Janoueix-Lerosey I, Novikov E, Monteiro M, Gruel N, Schleiermacher G, Loriod B, Nguyen C, Delattre O: Gene expression profiling of Ip35-36 genes in neuroblastoma. Oncogene 2004, 23:59/2-22.

20. Purrello M, Di Pietro C, Rapisarda A, Mirabile E, Motta S, Sichel G, Grzeschik KH: Genetic characterization of general transcription factors TFIIF and TFIIB of Homo sapiens sapiens. Cytogenet Cell Genet 1995, 69:75-80.

21. Purrello M, Di Pietro C, Rapisarda A, Viola A, Corsaro C, Motta S, Grzeschik KH, Sichel G: Genomic localization of the human gene for NC2 $\beta$, a negative modulator of transcription of class II and class III genes. Cytogenet Cell Genet 1996, 75:186-I89.

22. Purrello M, Di Pietro C, Viola A, Rapisarda A, Stevens S, Guerman M, Tao Y, Bonaiuto C, Arcidiacono A, Messina A, Sichel G, Grzeschik $\mathrm{KH}$, Roeder R: Genomics and transcription analysis of human TFIID. Oncogene 1998, 16:1633-1638.

23. Shimada H, Ambros IM, Dehner LP, Hata J, Joshi VV, Roald B: Terminology and morphologic criteria of neuroblastic tumors: recommendations by the International Neuroblastoma Pathology Committee. Cancer 1999, 86:349-63.

24. [http://research.marshfieldclinic.org/genetics/home/index.asp].

25. Cawkwell L, Bell SM, Lewis FA, Dixon MF, Taylor GR, Quirke P: Rapid detection of allele loss in colorectal tumours using microsatellites and fluorescent DNA technology. Br J Cancer 1993, 67: 1262-7.

26. [http://www.ebi.ac.uk/emboss/cpgplot/].

27. [http://repeatmasker.genome.washington.edu].

28. Tost J, Gut IG: DNA methylation analysis by pyrosequencing. Nat Prot 2007, 2:2265-2275.
29. Frommer M, McDonald LE, Millar DS, Collis CM, Watt F, Grigg GW, Molloy PL, Paul CL: A genomic sequencing protocol that yields a positive display of 5-methylcytosine residues in individual DNA strands. Proc Natl Acad Sci USA 1992, 89: I827-I83।.

30. Burdick D, Calimlim M, Flannick J, Gehrke J, Yiu T: MAFIA: A Maximal Frequent Itemset Algorithm. IEEE Transactions on Knowledge and Data Engineering 2005, 17:|490-I504.

31. Efron B, Tibshirani RJ: An introduction to the bootstrap. Chapman and Hall, New York, USA; 1993.

32. Mermelstein F, Yeung K, Cao J, Inostroza JA, Erdjument-Bromage $\mathrm{H}$, Eagelson K, Landsman D, Levitt P, Tempst P, Reinberg D: Requirement of a corepressor for DrI-mediated repression of transcription. Genes Dev 1996, 10:1033-1048.

33. Tonini GP, Romani M: Genetic and epigenetic alterations in neuroblastoma. Cancer Lett 2003, 197:69-73.

34. Kleinjan DA, van Heyningen V: Long range control of gene expression: emerging mechanisms and disruption in disease. Am J Hum Genet 2005, 76:8-32.

35. Hollams EM, Giles KM, Thomson AM, Leedman PJ: mRNA Stability and the Control Of Gene Expression: Implication for Human Disease. Neurochem Research 2002, 27:957-980.

36. Pillai RS, Bhattacharyya SN, Filipowicz W: Repression of protein synthesis by miRNAs: how many mechanisms? Trends Cell Biol 2007, I 1: I18-26.

37. Yu W, Gius D, Onyango P, Muldoon-Jacobs K, Karp J, Feinberg AP, Cui $H$ : Epigenetic silencing of tumour suppression gene p/5 by its antisense RNA. Nature 2008, $451: 202-6$.

38. Creton S, Svejstrup JQ, Collart MA: The NC2 alpha and beta subunits play different roles in vivo. Genes Dev 2002, 16:3265-76.

39. Mengus G, May M, Jacq X, Staub A, Tora L, Chambon P, Davidson I: Cloning and characterization of hTAFIII8, hTAFII20 and hTAFII28: three subunits of the human transcription factor TFIID. EMBO J 1995, I4:|520-3|

40. Hoffmann A, Oelgeschlager T, Roeder RG: Considerations of transcriptional control mechanisms: do TFIID-core promoter complexes recapitulate nucleosome-like functions? Proc Nat Acad Sci USA 1997, 94:8928-35.

4I. Kirschner DB, vom Baur E, Thibault C, Sanders SL, Gangloff YG, Davidson I, Weil PA, Tora L: Distinct mutations in yeast TAF(II) 25 differentially affect the composition of TFIID and SAGA complexes as well as global gene expression patterns. Mol Cell Biol 2002, 22:3 I78-93.

42. Ouzounis C, Sander C: TFIIB, an evolutionary link between the transcription machineries of archaebacteria and eukaryotes. Cell 1992, 71:189-190.

43. Maldonado E, Ha I, Cortes P, Weis L, Reinberg D: Factors involved in specific transcription by mammalian RNA polymerase II: role of transcription factors IIA, IID, and IIB during formation of a transcription-competent complex. Mol Cell Biol 1990, 10:6335-47.

44. Baek HJ, Kang YK, Roeder RG: Human Mediator enhances basal transcription by facilitating recruitment of transcription factor IIB during preinitiation complex assembly. J Biol Chem 2006, 28 I: | 5 | $172-8 \mid$.

45. Nowak MA, Komarova NL, Sengupta A, Jallepalli PV, Shih leM, Vogelstein $B$, Lengauer $C$ : The role of chromosomal instability in tumor initiation. Proc Natl Acad Sci USA 2002, 99:16226-3I.

46. Fodde R, Smits R: Cancer biology. A matter of dosage. Science 2002, 298:76I-3.

47. Purrello M, Di Pietro C, Rapisarda A, Amico V, Giunta V, Engel H, Stevens S, Hsieh Y, Teichman M, Wang Z, Sichel G, Roeder R, Grzeschik $\mathrm{KH}$ : Genes For Human General Transcription Initiation Factors TFIIIB, TFIIIB-Associated Proteins, TFIIIC2 and PTF/ SNAPC: functional and positional candidates for tumour predisposition or inherited genetic diseases? Oncogene 200I, 20:4877-4883. 